\section{Una rara avis: la evaluación continua}

Arcadi Gual, Jordi Palés-Argullós

\section{A rara avis: continuous assessment}

A nadie sorprenderá el interés que la Fundación Educación Médica (FEM) ha puesto en analizar y explicar el proceso de Bolonia y muy concretamente lo que representa este proceso para las enseñanzas de las ciencias de la salud en general y de la medicina en particular. Bolonia no es sólo una inflexión en el grado, la primera etapa del proceso de aprendizaje de los profesionales; Bolonia es un punto y aparte. Pero hoy no pretendemos hacer una reflexión general, sino simplemente exponer una preocupación concreta: la evaluación en los estudios de grado.

Los nuevos planes docentes han introducido la 'evaluación continua' argumentando que es lo que pide Bolonia. Cierto es que desde el inicio el Ministerio de Educación, responsable y competente en esta materia, no ha ayudado. Además de la evaluación continua, la ley obliga a una evaluación de toda la asignatura, como la de siempre. Pero eso lo podríamos pasar por alto, como si fuese una minucia. Una vez puestos en materia, la evaluación continua se pone a disposición de cada profesor para que la aplique a su asignatura. Bolonia habla de evaluación continua de competencias, competencias que presumiblemente se adquieren con los contenidos aportados por varias asignaturas $y$, por tanto, la evaluación exclusiva por asignaturas pierde sentido. Pero eso también lo podríamos pasar por alto, como si fuese una minucia. Cada profesor, versado en técnicas de evaluación o iletrado al respecto, aplica su criterio y posibilidades a la evaluación continua de su asignatura. No es posible a lo largo de un cuatrimestre desarrollar muchas pruebas porque no se dispone de tiempo, de los recursos materiales ni tampoco de profesorado suficiente para ello; una o dos pruebas es lo habitual, y excepcionalmente tres o cuatro cumplirán el requisito de llamar 'continua' a la evaluación. Pero como el propio profesor no confía mucho en lo que significa en términos de aprendizaje su propuesta de evaluación continua, decide que su evaluación continua valdrá,
The Fundación Educación Médica's (FEM) interest in analysing and explaining the Bologna Process - and more specifically the implications it has in the teaching of the health sciences in general and medicine in particular - will come as no surprise to anybody. Bologna is not just a turning point in the degree, a first stage in the professional's learning process; no, Bologna is a whole new beginning. But today our aim is not to deal with the matter in a general way, but to discuss one particular concern, i.e. assessment in degree studies.

The new teaching plans now include continuous assessment', claiming that it is required by Bologna. It is true that from the very outset the Spanish Ministry of Education, which is ultimately responsible for this issue, has done little to help the situation. In addition to continuous assessment, the law also requires some kind of evaluation of the whole subject, as has been the traditional method up till now. But this could be overlooked, as though it were just some minor detail. Once it is ready for use, the continuous assessment is made available to each lecturer so that they can apply it to their subject. Bologna speaks of continuous assessment of competencies, which are presumably competencies that are acquired with the material studied in several different subjects. It therefore makes little sense to assess students' progress by individual subjects. But this too could be overlooked, as though it were just some minor detail. Each lecturer, whether well versed in assessment techniques or illiterate in such matters, applies their own criteria and capabilities to the continuous assessment of their subject. It is not possible to carry out many tests in one term because of time restrictions, insufficient material resources and a shortage of teaching staff available for such duties. One or two tests can be seen as quite usual and three or four will be enough to be able to call the assessment 'continuous.' But since lecturers themselves have little faith in what their proposal for continuous assessment really means in terms of learning, they decide that the mark obtained in their continuous assessment will be added to the mark from the fi-
Fundación Educación Médica (FEM). Facultad de Medicina; Universitat de Barcelona. Barcelona, España.

Correspondencia: Arcadi Gual Sala. Departamento de Ciencias Fisiológicas I. Facultad de Medicina. Universitat de Barcelona. Casanova, 143. E-08036 Barcelona.

E-mail:

agual@ub.edu

Conflicto de intereses: No declarado.

Conflict of interests: None declared.

C 2012 Educación Médica 
junto a la prueba final de síntesis, para la nota final. Pero no valdrá mucho, no sea que los estudiantes aprueben sin saber la asignatura. El promedio de la evaluación continua de cualquier universidad española no llega a un valor de un $50 \%$ de la nota final. Pero eso también lo podríamos pasar por alto, como si fuese una minucia. Los estudiantes aprietan, lógicamente, y piden que las pruebas de la evaluación continua sean eliminatorias. Argumentar a los estudiantes que la 'evaluación continuada eliminatoria' no sólo no existe en ningún país del mundo, sino que es una contradicción en sí, resulta mucho más difícil que inventar la rueda cuadrada: por ello hemos inventado la 'evaluación continua eliminatoria, sobre la cual no encontrarán referencia bibliográfica alguna. Si han llegado a leer hasta aquí, aceptarán que en los grados en ciencias de la salud en las universidades españolas la evaluación continua de verdad es un fenómeno excepcionalmente infrecuente, una rara avis.

La responsabilidad de la evaluación en el grado es cosa de todos, los docentes, los discentes y la administración, incluidas las agencias de calidad universitaria, más cercanas a la propia administración que a la sociedad civil y los consejos sociales. Pero en estos momentos la evaluación de calidad en el grado, ajustada a estándares internacionales, no parece ser una preocupación para ninguno de los tres sectores. En el mejor de los casos se sigue evaluando como siempre, cuando no peor. ¿Es tan difícil leer un poco? Información y artículos de calidad contrastada sobre la evaluación continua los hay a cientos, quizá a miles. ¿Cuántas facultades han elaborado planes de estudio incluyendo un programa global de evaluación? La norma ha sido dejar la evaluación en manos de los responsables de cada asignatura. La institución responsable de un grado no puede garantizar a la sociedad una formación de calidad si no dispone de un programa de evaluación, un programa integral e integrado, organizado a lo largo de todos los años de formación. Si sólo se dispone de una evaluación compartimentada por asignaturas no estamos frente a una buena evaluación.

Disponer de un proceso de evaluación continua de los estudiantes no es un capricho para complicar la vida al profesor. La evaluación continua, indisociable del feedback que debe proporcionase al estudiante, es útil y necesaria para monitorizar la progresión del aprendizaje (feedback) y para tomar decisiones sobre su progreso (pasa/no pasa). Y esto es válido tanto para el profesor que imparte una asignatura como para la facultad que certifica un grado. Por ello, la evaluación ha de ser continua, engranada en un programa de la institución. Además del nal exam to give the final grade for the subject. But it won't count too much - we don't want students to pass without knowing the subject! The average value of the continuous assessment in any Spanish university never reaches $50 \%$ of the final grade. But this again could be overlooked, as though it were just some minor detail. Students logically try to put on some pressure and ask for the continuous assessment tests to be exemption exams (i.e. if they pass, they will not have to sit another exam on the same material). However, it would be far easier to invent a square wheel than to convince students that 'continuous assessment with exemption' is not only something that does not exist anywhere else in the world but is in fact a contradiction of terms. We have therefore come up with 'exemptive continuous assessment,' which you will not find cited anywhere in the literature. If you have read this far, you will agree that in health science degrees in Spanish universities real continuous assessment is an exceptionally rare phenomenon - a rara avis.

The responsibility for assessment in degree courses falls on everyone: teaching staff, students and administration, including the university quality assurance agencies, which stand closer to the administration itself than to civil society and social councils. But, today, evaluating the quality of the degree, which has been adapted to fit international standards, does not appear to be of great concern to any of the three sectors. In the best of cases, evaluation continues to be carried out as it has always been done, and in some cases things have got worse. Is it so hard to just read up on the matter a little? Proven high quality information and articles about continuous assessment abound in hundreds, perhaps thousands, of publications. How many faculties have drawn up curricula that include an overall programme of assessment? The norm has been to leave assessment in the hands of those responsible for each subject. The institution responsible for a degree cannot ensure high quality training if it does not have a programme of assessment; and this has to be a programme that is both integral and integrated, as well as organised to cover all the years the training is to last. If we only have assessment that is divided up by subjects, then we do not have good assessment.

Having a process that allows the continuous assessment of students is not some whim that was thought up in order to make life difficult for lecturers. Continuous assessment, which is inseparable from the feedback that students must be given, is useful and necessary for monitoring how they are progressing in the learning process (feedback) and for making decisions about their progress (pass/not pass). And this is valid both for the lecturer who teaches a subject and for the faculty that certifies a degree. Accordingly, 
sentido común, la literatura científica muestra que cuanto más importante sea la decisión a tomar (por ejemplo, certificar la adquisición de un grado), mayor ha de ser el número de actividades evaluativas que se deben disponer a lo largo del periodo evaluado. Solamente un número suficiente de puntos de referencia, estructurados y organizados dentro del programa de la institución, permitirán tomar las decisiones coherentes y justas que la sociedad demanda.

Una última apostilla. Hay demasiadas evidencias que apoyan la necesidad de movernos desde el discurso psicométrico dominante, basado en pruebas estructuradas y tests de toda índole, hacia actividades de evaluación no paramétricas, personalizadas y realmente continuas, en las que el profesorado experto en evaluación saque todo el fruto de su experiencia para mejorar el rendimiento del estudiante. La evaluación continua no ha de servir sólo para la nota final, la evaluación continua es uno de los instrumentos del aprendizaje. Utilizar la evaluación continua como instrumento de formación no es optativo para el profesor, es una obligación. La investigación en el campo de la educación médica nos proporciona cada día nuevos instrumentos para evaluar diferentes aspectos de la formación de los médicos. Entre los instrumentos encontramos de todo tipo, complejos de aplicar o especialmente sencillos. Los hay económicos y los hay caros. Los hay fiables, consistentes y reproducibles. Saber escoger el instrumento adecuado para cada evaluación, en cada momento y en cada lugar no puede ser fruto de la tradición (siempre se ha hecho así y los resultados son buenos), ni tampoco de la moda (es el último instrumento publicado). La elección del instrumento de evaluación no ha de seguir otro criterio que el mismo utilizado en la investigación biomédica, el criterio científico. Expertos en contenidos biomédicos no nos faltan, pero expertos, o al menos buenos conocedores, del proceso evaluador no nos sobran. Entre otras misiones, ésta es una de las relevantes de las unidades de educación médica. Es necesario que los docentes, buenos conocedores de los contenidos específicos, se asesoren de los expertos en evaluación. Es especialmente necesario formar a los docentes en evaluación formativa, la evaluación continua, que como ha quedado claro trasciende a la evaluación de cada asignatura.

La evaluación, y muy especialmente la evaluación continua, sigue siendo una asignatura pendiente en los estudios de grado en ciencias de la salud y en concreto en el grado de medicina. Resolverlo no será fácil, pero la pregunta a formular es: ¿cuándo decidiremos abordarlo? assessment must be continuous and engaged within a programme drawn up by the institution. Apart from being a matter of common sense, the scientific literature also shows that the more important the decision to be made is (for example, certifying the awarding of a degree), the more evaluative activities have to be made available throughout the period under assessment. Only a sufficient number of points of reference (all structured and organised within the programme of the institution) will allow the decisions required by society to be taken in a coherent and fair manner.

One last remark. There is a vast amount of evidence supporting the need to move away from the dominant psychometric discourse, based on structured exams and all kinds of tests, and set our sights on assessment activities that are non-parametric, personalised and truly continuous, in which members of teaching staff who are experts in evaluation draw on all their experience to improve their students' performance. Continuous assessment is not to be used as just a part of the final grade - it is a valuable instrument to foster learning. Using continuous assessment as a training tool is not something teaching staff can choose to do: it is mandatory. Every day research in the field of medical education provides us with new instruments for evaluating different aspects of the training received by doctors. These include instruments of all different kinds - some that are difficult to apply and others that are especially simple. Some of them are economical and others are costly. Some are reliable, robust and reproducible. Knowing how to pick the instrument that is best suited to each evaluation, in each moment and in each place cannot be something that just follows a tradition (that's how it's always been done and it gives good results) or some craze (it's the latest instrument to appear in the literature). The choice of which assessment tool to employ must follow the same criteria as those used in biomedical research, i.e. scientific criteria. There is no shortage of experts in biomedical matters, but we can hardly say there is a surplus of experts in the assessment process (or at least people with a thorough knowledge of it). Among the different missions of medical education units, this is one of the most significant. Teachers, who have a good knowledge of the specific contents of their area, must consult experts in assessment. There is a distinct need to train members of teaching staff in formative assessment, in continuous assessment, which as we have seen goes beyond merely evaluating each subject.

Assessment, and more especially continuous assessment, is an issue that remains unresolved in health science degree studies and particularly in medical degrees. Settling it will be no easy matter, but the question is: when will we actually get round to addressing it? 
Bibliografía / References

1. Van der Vleuten C. Validity of final examinations in undergraduate medical training. BMI 2000; 321: 1217.

2. Palés-Argullós J. La progresiva adquisición de competencias en la formación médica. Cursos de Verano de la Universidad Complutense. San Lorenzo de El Escorial, Madrid, julio de 2012.

3. Van der Vleuten C, Schuwirth LWT, Driessen EW, Dijkstra J, Tigelaar D, Baartman LKJ, et al. A model for programmatic assessment. Med Teach 2012; 34: 205-14. 